sciendo Порівняльна професійна педагогіка 9(4)/2019 Comparative Professional Pedagogy 9(4)/2019

DOI: $10.2478 /$ rpp-2019-0035

$\mathrm{PhD}$ in Pedagogy, Associate Professor, IHOR ROSKVAS

Khmelnytskyi National University

Address: 11 Instytutska St., Khmelnytskyi, 29016, Ukraine

E-mail: ihor219115@gmail.com

\title{
CONTINUING TRAINING OF LANGUAGE TEACHERS IN THE UK
}

\begin{abstract}
This paper emphasizes the fact that the current socio-cultural conditions in Ukraine put fundamentally new requirements on professional training of future language teachers. Furthermore, the reforms in Ukrainian higher education, including its focus on the implementation of the principles of the Bologna Declaration, expect that continuing teacher training of future language teachers should result in professionally mobile, proactive and independent future language teachers. Therefore, this paper aims to analyze the continuing teacher training of future language teachers in the UK and suggest ways to improve continuing teacher training of language teachers in Ukraine. The paper indicates that the UK is at a turning point today. The country is on its way of leaving the EU, which will significantly change not only its relations with EU countries but also with other countries all over the world. Thereby, the UK needs the skills and capabilities, which will facilitate the understanding of other cultures and languages, to continue to be important for successful international relationships at all levels. The four nations of the UK have approached policy on language education in different ways, which reflect their different linguistic circumstances, and they will continue to do so. The paper states that the model of the UK language teacher includes not only professional qualities but also his or her professional and personal development in the context of professional training and retraining. The paper concludes that the use of the UK's positive experience in providing continuing teacher training to language teachers and ensuring their professional development discovers some new opportunities for Ukraine. Further research should focus on the peculiarities of the programmes for the professional development of language teachers. It can help to enhance the quality of advanced training of language teachers in Ukraine.
\end{abstract}

Keywords: teacher, language teacher, the UK, teacher training, continuing teacher training.

\begin{abstract}
АНОТАЦІЯ
У статті наголошено на тому, що сучасні сочіокультурні умови в Украйні висувають принципово нові вимоги до професійної підготовки майбутніх учителів іноземних мов. Крім того, реформи в украӥнській вищій освіті, включно ї̈ спрямованість на реалізацію принципів Болонської декларачії, передбачають, що неперервне навчання майбутніх учителів іноземних мов повинно мати на меті підготувати професійно мобільних, ініціативних та незалежних фахівиів. Таким чином, метою иісї наукової статті є вивчення особливостей безперервного навчання майбутніх учителів іноземних мов у Великій Британії для того, щоб запропонувати шляхи вдосконалення такої підготовки в Украӥні. У статті зазначено, що наразі Велика Британія перебуває на шляху від'єднання від Європейського Союзу, який суттєво змінить не лише відносини иієї краӥни з краӥнами СС, але також з іншими краӥнами світу.
\end{abstract}


sciendo Порівняльна професійна педагогіка 9(4)/2019 Comparative Professional Pedagogy 9(4)/2019

Отже, Велика Британія потребує фахівиів, які володіють навичками ведення міжкультурного діалогу $і$ здатні полегшити розуміння інших культур, мов та націй для того, щуоб підтримувати власну авторитетну позицію на світовій арені. Проаналізовано, що професійна модель вчителя іноземних мов у Великій Британї включає у себе не лише професійні якості, а також професійний та особистісний розвиток вчителів у контексті їхньої професійної підготовки та перепідготовки. У статті зроблено висновок про те, ще використання позитивних аспектів досвіду Великої Британії щодо провадження неперервної підготовки вчителів іноземних мов та забезпечення їхнього професійного розвитку відкриває для Украйни нові можливості. Подальші наукові розвідки повинні стосуватися вивчення особливостей програм для підвищення кваліфікачії вчителів іноземних мов, оскільки таким чином можливо підвищити якість підвищення кваліфікації вчителів іноземних мов в Украӥні.

Ключові слова: вчитель, вчитель іноземних мов, Велика Британія, підготовка вчителів, неперервне навчання вчителів.

\section{INTRODUCTION}

The current socio-cultural conditions in Ukraine put fundamentally new requirements on professional training of future language teachers. A renewed school requires that future language teachers should able to engage in the personal and individual development of every pupil and student and be ready to enhance the education system to meet the needs of the individual, society and the state. The reforms in Ukrainian higher education, including its focus on the implementation of the principles of the Bologna Declaration, expect that continuing teacher training of future language teachers should result in professionally mobile, proactive and independent future language teachers. Ukrainian higher education institutions (HEIs) has accumulated some innovative experience in training future language teachers. However, as practise has shown, it is somewhat behind the current requirements.

Therefore, the quality assurance system of continuing teacher training in the UK as one of the oldest countries in Europe is of particular scientific interest for modern reforms in education, as well as pedagogical science and practice in Ukraine.

Despite the centuries-old educational traditions, the UK system of teacher training was developed only in the last century. However, the country is on the path to reforming and improving the education system, in particular, professional training of language teachers, as a young and rapidly developing sub-system of the country's education system. Indeed, the UK has become one of the first countries to implement the principles stated in the Bologna Declaration. In shifting to the principles of the Bologna Declaration, the UK has managed to retain the specifics of the national higher education system, including teacher training, and promote its educational traditions at the pan-European level. The Ukrainian pedagogical science and practice are interested in finding answers to the following questions:

1. How do specialists from the UK diversify educational routes and individualize teacher training of future language teachers?

2. How do they ensure the continuity of teacher education and enhance the system of advanced teacher training for language teachers?

3. How do they implement a competency-based approach and assure the quality of teacher training following the Bologna Declaration?

For many years in the UK, they have been researching the field of continuing teacher training of language teachers and have been reinforcing a theoretical and practical 
sciendo Порівняльна професійна педагогіка 9(4)/2019 Comparative Professional Pedagogy 9(4)/2019

basis for developing this field through the country's participation in various international projects. The importance of studies on the UK system of quality training and retraining of future language teachers for Ukrainian pedagogical science and practice is evidenced by the fact that it originally functioned under limited state financing, which facilitated the development of market mechanisms of its organization, independent search for sources of financing and activation of marketing sources. Given the perpetual preservation of national priorities, this model has evolved in line with pan-European and global trends, addressing many of the problems of teacher training of language teachers in many countries around the world. In this regard, the learning from the UK experience will allow Ukrainian agents of educational changes to understand not only the global trends in the quality of teacher training of language teachers but also the nature of existing problems and ways of solving them, and thereby help to minimize the potential negative consequences and mistakes, as well as compare Ukrainian political decisions with the practice of others, evaluate the appropriateness and risks of making them better.

\section{THE AIM OF THE STUDY}

Thereby, this paper aims to analyze the continuing teacher training of future language teachers in the UK and suggest ways to improve continuing teacher training of language teachers in Ukraine.

\section{THEORETICAL FRAMEWORK AND RESEARCH FRAMEWORK}

The theoretical framework of this research relies on the individualization, generalization and systematization of the relevant studies and documents regarding the demand for language specialists in the UK, the UK language policy and the characteristics of teacher training of language teachers.

In 2012, the Confederation of British Industry surveyed employers from 542 companies and found out that almost three-quarters of employers from the UK's private sector needed employees proficient in languages (Tinsley, 2013). Therefore, the structure of the labour market following the demand for language skills covers five levels (see Fig. 1).

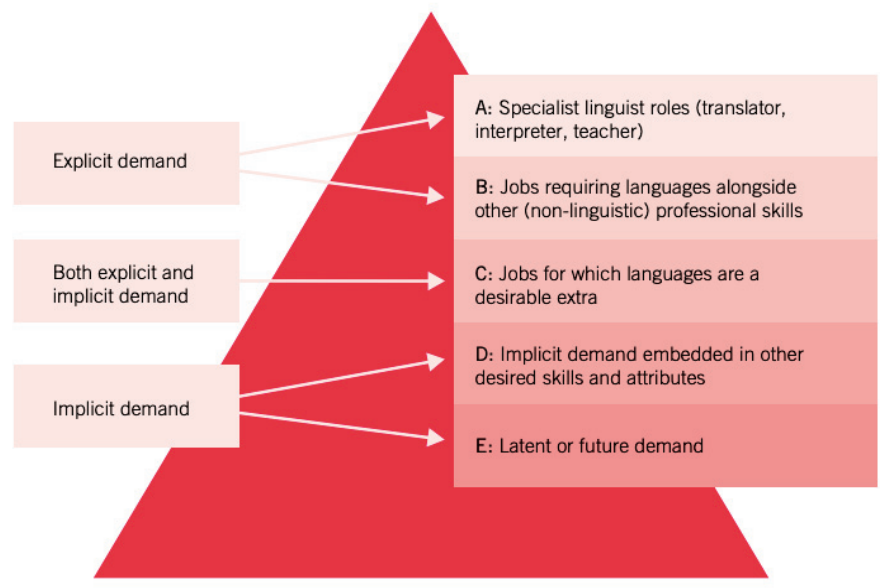

Fig. 1. The structure of the UK labour market for language specialists

Source: Tinsley, T. (2013). Languages: the state of nation. Demand and supply of language skills in the UK. Retrieved from https:/www.thebritishacademy./ac.uk/ sites/default/files/State_of_the_Nation_REPORT_WEB.pdf. 
sciendo Порівняльна професійна педагогіка 9(4)/2019 Comparative Professional Pedagogy 9(4)/2019

Thus, the level of specialist linguist roles (translator, interpreter, teacher) encompasses a small percentage of jobs (about $6 \%$ ) where language skills are a prerequisite for employment. There is also a continuing need for interpreters and translators to work in international organizations such as the UN. Besides, there are downward trends in the provision of the British Justice System with simultaneous translators. T. Tinsley (2013) believes that the demand for language teachers should increase as the UK government actively develop innovative strategies for the sector of higher education.

However, the most significant percentage of jobs for which language proficiency can be required is concentrated in sectors that typically require languages alongside other (non-linguistic) professional skills. According to the data of Labour Market Intelligence, terms such as "accounts", "marketing", "public relations" or "sales" are most commonly used in job vacancies in the language sector. The next level concerns jobs for which languages are a desirable extra. It must be acknowledged that only $20 \%$ of employers are not interested in the language skills of employees. However, only some of them clearly state their position during the interviews with candidates. Therefore, this level indicates both explicit and implicit demand for language skills of specialists. Besides, employers do not value language proficiency as much as the skills that employees acquire through learning foreign languages, in particular, the skills of international cooperation and intercultural interaction (implicit demand embedded in other desired skills and attributes). One can also observe latent or future demand driven by the ambiguous behaviour of employers regarding hiring foreign citizens. A survey of employers in more than 30 European countries shows that employers from the UK are most interested in specialists from non-European countries (an average indicator throughout Europe is $21 \%$; throughout the UK $-49 \%)$. On the other hand, the UK is actively recruiting specialists from other European countries (an average indicator throughout Europe is $30 \%$; throughout the UK 57 \%) (British Academy, 2011; Tinsley, 2013; UUK, 2012; 2013; 2014; 2015; 2016; 2017).

Today, the UK is at a turning point. The country is on its way of leaving the EU, which will significantly change not only its relations with EU countries but also with other countries all over the world. Thereby, the UK needs the skills and capabilities, which will facilitate the understanding of other cultures and languages, to continue to be important for successful international relationships at all levels.

The four nations of the UK have approached policy on language education in different ways, which reflect their different linguistic circumstances, and they will continue to do so. However, all should recognize that the UK's language deficit remains a threat to their overall international competitiveness, influence and standing in the world, as well as to their citizens' ability to play a meaningful role in the global economy and in an increasingly networked world. following:

T. Tinsley and K. Board believe that the four UK governments should do the

-to initiate a new bold policy to improve language learning for a transformed "global Britain";

- to meet business and organizational needs for language capacity;

- to provide better advice to companies in using and managing language skills;

-to set and ensure adherence to minimum time requirements for language teaching at primary and secondary levels;

-to consider the country's future need for international capacity post-Brexit and give strategic protection to specialist expertise in languages and cultures; 
sciendo Порівняльна професійна педагогіка 9(4)/2019 Comparative Professional Pedagogy 9(4)/2019

- to develop and incentivize take-up of, the offer of languages as additional modules or integrated units within vocational and degree courses in further and higher education;

-to protect and prioritize education exchange programmes in EU exit negotiations and guarantee their continuation ideally via the UK retaining full membership of the Erasmus + programme (Report on Languages for the Future, 2017).

These objectives are in line with the existing concept of continuing teacher training of language teachers in the UK. However, the country strives to enhance its quality under today's challenges and requirements. Still, one should analyze the characteristics of continuing teacher training of language teachers in the UK experience to suggest ways to improve continuing teacher training of language teachers in Ukraine.

\section{RESULTS}

The study of conceptual principles for quality assurance of continuing teacher training of future language teachers in the UK concludes that the model of the UK language teacher includes not only professional qualities but also his or her professional and personal development in the context of professional training and retraining (Gomez-Cash, 2016).

Regarding pedagogical activities of language teachers, their most effective teaching skills are the following: ability to explain the curriculum clearly; ability to inspire pupils; ability to teach pupils to understand rather than simply reproduce the educational material; ability to perceive events adequately; ability to communicate and interact; the ability to organize group work and establish positive relationships in the classroom. Thus, continuing teacher training of future language teachers in the UK aims to identify priority areas for enhancing its quality (Bowskill, 2010).

By the end of the 20th century, the UK adopted two conceptual approaches to assessing the quality of teachers' professional and personal development in the system of lifelong learning. The first approach is based on the idea of adjusting teacher training to social demand, which is based on acquiring the teacher's professional competency. This approach illustrates a rather mechanistic view of the teacher's role in the UK system of education, ignoring the role of experience in the practical application of knowledge and self-evaluation.

The second approach involves evaluating the quality of teacher training and retraining based on the concept of practical abilities and skills, which rely on the practical experience determining the stages of development when moving from a novice teacher to an expert. This approach acknowledges the need for continuity of the training process during initial training and further professional development aimed at revealing the inner potential of the individual, as well as improving his or her self-motivation and intellectual activities (Bowskill, 2010).

Thus, the development of abilities required to optimize the training process through practical experience becomes a significant challenge in the professional development of language teachers. The study of government documents, as well as the works of British researchers, shows that the specificity of continuing teacher training of language teachers in the today's system of the UK education is the concept of lifelong learning proposed by UNESCO, which puts the individual at the heart of all educational starts.

In the UK, there are three types of professional development of language teachers (personal, professional and theoretical, professional and practical) and three areas in the development of languages teachers as individuals, theoretical specialists (a broad concept, including a constant desire to acquire professional knowledge, abilities, skills) and practising teachers as organizers of the educational process (a narrow concept implying the application of acquired knowledge in practice). 
sciendo Порівняльна професійна педагогіка 9(4)/2019 Comparative Professional Pedagogy 9(4)/2019

The basic needs of professional development of language teachers in the UK include individual and personal (non-professional); professional (career, long-term educational needs); purposeful (active storage of knowledge, needs for skills). One should also pay particular attention to taking into account the factors of career development for language teachers. The advancement of their professionalism is related to their characteristics, motives and actions for professional development, their socialization in the pedagogical environment and society. Nowadays, the development of continuing teacher training of language teachers is mostly associated with the growing role of the teacher's personality and the focus of the educational process in HEIs in the UK to change the spiritual values and develop those qualities of the teacher's personality, which they need in future practical activities (Gomez-Cash, 2016).

In many contexts, it is rather tricky, however, to implement continuing teacher training through the professional development of teachers, including language teachers. According to a report conducted by Cambridge Assessment English (2018), there are some challenges which negatively affect the influence of programmes for professional development. They are the following (Cambridge Assessment English, 2018):

1) a top-down centrally mandated approach. It somewhat limits the choices of language teachers regarding the areas of development. In this case, language teachers view compulsory professional development as such, not meeting their needs;

2) teachers as passive recipients of the information. It is impossible to generate long-term positive changes if languages teachers are simply told what to do, are provided with materials and are not given the opportunities to develop skills required to influence pupil learning;

3) a 'one-size fits all' approach. This approach cannot differentiate professional development of language teachers based on the existing levels of their experience and knowledge. Also, it does not allow integrating it into their teaching practice, given personal and cultural contexts. Besides, it fails to meet the individual needs of language teachers, being cost-effective but not productive pedagogically;

4) failure to address the teaching - curricula - assessment link. The standards of professional development of language teachers cannot be improved only after introducing English in compulsory education and increasing the number of instruction hours in English. Besides, one can observe some mismatch between the goals of the curriculum and the focus of continuing teacher training of language teachers;

5) management factors associated with the challenges of large-scale programme implementation on a regional or national level. It is essential to monitor and evaluate the influence of programmes for professional development and set realistic goals of advanced training of language teachers.

At the same time, the professional development of language teachers can be successful if both teachers and students are the heart of this process. It requires the following (Cambridge Assessment English, 2018):

1) localized and context-specific approaches. It is essential to take into account different contexts when elaborating programmes for the professional development of language teacher, including the peculiarities of the education system and cultural environments in which these teachers work. These programmes should help language teachers to consolidate the knowledge and skills they have obtained earlier;

2) growth mind-set. It is essential to help language teachers to improve their knowledge and practice and focus on their strengths rather than weaknesses. Languages teachers should strive for long-term positive changes in professional activities; 
sciendo Порівняльна професійна педагогіка 9(4)/2019 Comparative Professional Pedagogy 9(4)/2019

3) relevant, differentiated and supported programmes. It is crucial to integrate professional development into the daily professional life of language teachers so that it can be situated not only in training rooms but also in schools and classrooms. It is also necessary to support language teachers financially in doing so or reduce teaching loads;

4) bottom-up/top-down synergy. Indeed, language teachers act as the interface between top-down policy requirements and bottom-up needs of pupils and students. Therefore, it is vital to involve them in discussions about the content of professional development and meet their professional needs;

5) reflection and critical engagement. Language teachers should be able to reflect on the experience in professional development. After all, they can improve their professionalism only if they can learn from the experience of other teachers;

6) collaboration and mentoring. Programmes for the professional development of language teachers must involve collaboration and expert mentoring since these are the most significant components of this process;

7) theory and practice. Language teachers should be able to integrate the acquired theoretical and practical knowledge in the practical context;

8) range of competencies. Language teachers should have the following competencies: advanced competence in English, subject matter knowledge, practical methodological skills and competence in broader issues;

9) integration of teaching, curricula and assessment. It is essential to establish the long-term links between teaching, curricula and assessment to move away from shortterm prospects of professional development of language teachers;

10) observable, realistic and efficient outcomes. It is crucial that language teachers can track their progress while participating in programmes for professional development so that they can fix their weaknesses and reinforce their strengths.

\section{CONCLUSIONS}

Therefore, the use of the UK's positive experience in providing continuing teacher training to language teachers and ensuring their professional development discovers some new opportunities for Ukraine. First of all, it is necessary to build a highly effective process of preparing language teachers for professional and personal intercultural interaction in the changing world. Second, the implementation of such UK's experience in Ukrainian higher education institutions offering teacher education can improve the process of developing new technologies for professional training of language teachers and reach the level of modern scientific and pedagogical achievements.

Further research should focus on the peculiarities of the programmes for the professional development of language teachers. It can help to enhance the quality of advanced training of language teachers in Ukraine.

\section{REFERENCES}

1. British Academy. (2011). Language matters. A position paper. Retrieved from https://www.britac.ac.uk/sites/default/files/LanguageMatters2_0.pdf.

2. British Council. (2017). Report on Languages for the Future (the foreign languages the United Kingdom needs to become a truly global nation). Retrieved from $\mathrm{http} / / / \mathrm{www}$. ciol.org.uk/sites/default/files/languages_for_the_future_2017.pdf.

3. Bowskill, S. (2010). Guest editorial: considering postgraduate study in languages, linguistics and area studies? Debut: the Undergraduate Journal of Languages, Linguistics and Area Studies, 1 (2), 45-47. 
sciendo Порівняльна професійна педагогіка 9(4)/2019 Comparative Professional Pedagogy 9(4)/2019

4. Cambridge Assessment English. (2018). Cambridge Assessment English perspectives. Teacher professional development. Retrieved from https://www.cambridgeenglish.org/Images/ 539683-perspectives-teacher-professional-development.pdf.

5. Gomez-Cash, O. (2016). Professional contexts for modern languages: work experience and academic reflection in a multilingual context. In E. Corradini, K. Borthwick \& A. Gallagher-Brett (Eds.), Employability for Languages: a Handbook (pp. 57-66). Dublin: Research-publishing.net.

6. Tinsley, T. (2013). Languages: the state of nation. Demand and supply of language skills in the UK. Retrieved from https://www.thebritishacademy.ac.uk/sites/default/files/ State_of_the_Nation_REPORT_WEB.pdf.

7. Universties UK. (2012). Patterns and trends in UK higher education. Retrieved from http://www.universitiesuk.ac.uk/policy-andanalysis/reports/Documents/2012/higher-education-facts-and-figures-2012.pdf.

8. Universities UK. (2013). Patterns and trends in UK higher education. Retrieved from http:/www.universitiesuk.ac.uk/policy-andanalysis/reports/Documents/2013/patterns-and-trends-uk-higher-education-2013.pdf.

9. Universities UK. (2014). Patterns and trends in UK higher education. Retrieved from http://www.universitiesuk.ac.uk/policy-andanalysis/reports/Documents/2014/patterns-and-trends-in-uk-higher-education-2014.pdf.

10. Universities UK. (2015). Patterns and trends in UK higher education. Retrieved from http://www.universitiesuk.ac.uk/policy-andanalysis/reports/Documents/2015/patterns-and-trends-2015.pdf.

11. Universities UK. (2016). Patterns and trends in UK higher education. Retrieved from http://www.universitiesuk.ac.uk/facts-and-stats/data-andanalysis/Documents/patterns-and-trends-2016.pdf.

12. Universities UK. (2017). Patterns and trends in UK higher education. Retrieved from http://www.universitiesuk.ac.uk/facts-and-stats/data-andanalysis/Documents/patterns-and-trends-2017.pdf. 